Renshaw, Layla (2020) Unrecovered objects : narratives of dispossession, slow violence and survival in the investigation of mass graves from the Spanish Civil War. Journal of Material Culture, 25(4), pp. 428-446.

Copyright (C) The Author 2020. DOI: https://doi.org/10.1177/1359183520954499 


\section{Unrecovered Objects: Narratives of Dispossession, Slow Violence and Survival in the Investigation of Mass Graves from the Spanish Civil War}

\section{Introduction}

The Spanish Civil War (1936-9) was a period of sustained, widespread violence, which engulfed the country, leaving a legacy of profound trauma and loss. It was triggered by a military coup organized by General Francisco Franco against a democratically-elected progressive government. Alongside conventional warfare, the war was characterized by episodes of intense violence perpetrated against non-combatants, resulting in massacre sites and clandestine mass graves in many regions of Spain. It has been estimated that over 175,000 people were killed away from the battlefields during the Spanish Civil War (Preston, 2012; Ríos et al., 2014). The conflict ended with a total victory for Franco's forces and the initiation of his regime as dictator, which endured until 1975. The post-war years were a punitive period characterized by the mass imprisonment of defeated combatants, summary justice, and localised retributive violence, which added to the death toll of the war (Marco, 2019; Preston, 2012). For close to forty years there was no democracy, and many repressive strategies directly targeted the collective identity of the dead and concertedly suppressed the memory of murdered Republicans (Renshaw, 2011; Rodrigo, 2008; Graham, 2004). Following the death of Franco, a successful, largely peaceful, transition to democracy occurred, but avoided confronting the traumatic past, a process sometimes characterized as the "pact of silence' or the 'pact of amnesia' (Aguilar, 2002; Tremlett, 2006).

In 2000, a journalist called Emilio Silva travelled back to his ancestral village to recover the remains of his grandfather, who had been killed by Francoists in the Civil War and buried in a clandestine grave (Silva and Macías, 2003; Silva, 2000). The network drawn together by this exhumation grew into a grassroots organization, the Association for the Recovery of Historical Memory (ARMH). Since the inception of ARMH, thousands of graves across Spain have been opened, with recent estimates suggesting over 8,000 bodies recovered (Etxeberria, 2016). The investigations spearheaded by ARMH, and a mosaic of smaller organizations, have coalesced into a nationwide campaign, producing a radical rupture in Spain's memory politics (Ríos \& Etxeberria 2016). The exhumations have triggered a new phase of engagement with the Civil War (Ferrándiz, 2006; Fernández de Mata, 2004; González-Ruibal, 2007). 
This article explores a recurring narrative form within Civil War memory and testimony. It focuses on a set of thematic preoccupations concerning theft, dispossession and the covetous envy of material things. It draws on ethnographic fieldwork in a number of villages as they underwent the investigation of mass graves in their midst, recovering the bodies of Republican war dead, who were former inhabitants of these communities, and relatives to many of the present-day residents. These narratives surface with notable frequency as part of wider conversations that accompany the exhumation of mass graves in small rural communities. In these accounts, the appropriation of goods and possessions is an important causal factor invoked to explain the killings that occurred in these places. Episodes of theft, both concurrent to the killings and throughout the subsequent years of war and dictatorship, are identified as central transgressions committed by the Francoist forces and their sympathizers. A stolen object, sometimes precious, sometimes mundane, frequently structures the narrative account, even when other intensely violent acts are described. Particularly with the very elderly, the evocation of a theft, or a particular missing object, appeared to be a mnemonic touchstone or trigger, eliciting an intense period of recollection, or animated exchanges with peers and investigators, within conversations that had hitherto been halting and drifting.

There are multiple points of tension and divergence between the traumatic memory revealed by these narratives of theft, and the investigative paradigm of mass grave exhumation. The mass grave paradigm encodes certain assumptions, namely that the primary crime is murder, the primary victims are the dead in these graves, and that war is characterized by cataclysmic outbursts of extreme violence. Even more fundamental to the endeavor of forensic and archaeological investigation, is the premise that the past can be verified via its physical traces, not merely its psychic, affective and imaginary traces. Implicit in the forensic paradigm is a belief that the recovery and scrutiny of these physical traces can be a transformative, redemptive and therapeutic act (Moon, 2013; 2014; Rosenblatt, 2015; Steele, 2008). The forms of memory encountered in some communities and families in Spain, invite us to be critical of all these assumptions. Indeed, the tension between a trauma-catharsis-closure model of mass grave exhumation, and the complex realities of Spanish Civil War memory, has been flagged by Bevernage and Colaert (2014). 
This article will explore what can be learned about experiences of mass violence, collective terror, and long-term repression by being attentive to the forms of the locallymeaningful emic memory that have survived these assaults. I argue that the stolen objects are particularly potent for encoding the experiences of defeat, dispossession, and post-war survival, and by extension, representing the mothers and female relatives who endured these experiences. This is not simply due to the mothers' economic struggles but due to a series of figurative and imaginative associations between the lost objects and the lost biographies of these women, and specific forms of memory transmission in Republican homes. These narratives of theft reveal the importance of slow violence. They foreground women and children's survival of war and dictatorship, and the ways gender, affect and imagination mediate the transmission of memory (Reading, 2002). Dominant associations between war and masculinity, and the potential for this to crowd out female experiences, have been noted in other historical contexts (McDowell, 2008). I argue here that the recounting of narratives of theft and dispossession, in the midst of mass grave investigations, reflects a justified anxiety, amongst local communities and families, that the exhumations, with their inherent focus on death, will not address these hidden histories of survival.

Further historical context is necessary to understand the gendered dimensions of wartime violence and post war repression in Spain. The more egalitarian and feminist ethos of the Spanish Left, and the rapid social changes experienced in the decade prior to 1936, brought unprecedented progress in women's opportunities and rights (Ryan, 2014, 17). Women were actively engaged in politics before and during the Civil War. Republican women were on the battlefield in both combat and support roles (Herrmann, 2003; Lines, 2009). Francoism also mobilised its female supporters, primarily through the Sección Femenina (Richmond, 2014). These above authors on female Republican activism have noted the concerted effort by Francoist forces to punish and repress any manifestation of Leftist or feminist ideas amongst women, pathologise feminism (Richards, 2001), and enforce retrograde models of femininity as part of 'National Catholicism'. The assertion of masculinist norms permeated Francoist ideology and rhetoric on a deep level (Box 2017a; 2017b). 
The type of killings under investigation in my field sites, and experienced widely in the Civil War, took the form of extrajudicial political murders. These were known as paseos when civilians were abducted from their homes, or as sacas when detained civilians were rounded up from police and prison cells and killed without due process (Renshaw, 2011, 47). Women were killed in these paseos, but in considerably smaller numbers than men (Sole, 2017). However, other forms of extreme gendered violence against Republican women frequently accompanied or followed the paseos. After Republican men were killed, their surviving female relatives were terrorized. Beatings, assaults, and rape occurred in high numbers, enacted both by military forces and local perpetrators. The highly ritualized public humiliation of Republican women, including bodily purging and head-shaving, was reported by numerous informants in my field sites, and in communities throughout Spain. Post-war, surviving Republican women were subject to decades of persecution including imprisonment, family separations, surveillance, sexual exploitation and the appropriation of their labour for unpaid work in Francoist homes and institutions (see Amir, 2019; Fidalgo, 1939; Vinyes, 2002; Osborne, 2011; Ryan, 2009; Graham, 1995a).

The mass appropriation of material possessions and property also characterised the Spanish Civil War and early post-war period. This took the form of theft, looting, forced exile, fines for political crimes and coerced donations (Casanova \& Cenarro, 2014). Del Arco Blanco \& Anderson (2017) highlight the importance of this huge transfer of wealth to the forging and consolidation of the Francoist state. The scale of thefts in my field sites ranged from seized land and homes, to domestic goods, clothes and foodstuffs (Renshaw, 2011). Popular participation in theft and appropriation enabled the reward of supporters, as well as disempowering the losing side; 'many supporters of the Republic who lost property to their Francoist neighbours suffered both the physical and symbolic dispossession of power, status and agency.' (Del Arco Blanco \& Anderson, 2017, 74). A growing body of scholarship now implicates the ruling elite of the dictatorship as the beneficiaries of large-scale transfers in property (Maestre, 2019; Sánchez Soler, 2003; Viñas, 2015). These experiences of political repression, gendered violence, and economic dispossession are the context in which the particular memorial forms discussed in this article, have emerged. 
The accounts of exhumation and interview excerpts included in this article come from ethnographic fieldwork conducted between 2003 and 2008, assisting on mass grave excavations as an archaeologist in Castile and Leon, Asturias, and Extremadura. I conducted participant-observation amongst a number of teams of archaeologists and forensic specialists, and ethnographic interviews including life and family history narratives amongst survivors, witnesses, and relatives of the dead. Those relatives of the dead who agreed to share life and family histories, as well as participate in semistructured interviews about the mass grave investigation and its outcomes, were largely those who had already engaged with the memory campaign or the ongoing investigation in their community. In this respect they were a partial sample of the community - those who were broadly supportive, or at least curious and open-minded about the mass grave exhumation. This ethnographic material includes some interviews and observations that are over a decade old, but as a window into the lived experience of war and repression, it remains relevant. Over the intervening decade, the memory landscape in Spain has undergone tectonic shifts, as evinced by the current government's fiercely critical position on Franco's legacy, and its material manifestations at the Valle de los Caidos. The government's decision in 2019 to exhume Franco's body from the monument that the dictator designed for himself, and rebury him in a family mausoleum in the El Pardo municipal cemetery, would have been unthinkable a decade ago. Conversely, these shifts make an ethnographic snapshot of the early days of a memory campaign more interesting. Further reflection on this period is valuable for a more nuanced assessment of the impact of the memory rupture in contemporary Spain, as a window onto the kind of emic memory that had survived both dictatorship and the 'amnesia' of democracy.

\section{Narratives of Theft and Dispossession from the Spanish Civil War}

Turning to ethnographic examples, it is useful to establish some examples of how narratives of theft were invoked in my field sites. The categories of material object that were the focus of these narratives, the ethnographic context in which they came up, and points of emphasis or narrative tropes contained within them all repay close attention. On a number of occasions, the specialist practitioners, local ARMH coordinators and volunteers would initiate conversations about the potential for the personal possessions of the dead to be recovered in the mass graves. They explained that if relatives of the 
dead could remember or recognize any of these objects, these memories could contribute to the successful identification of the dead. A related and parallel line of questioning by those gathering oral histories, and which I pursued in my own interviews, concerned the retention or inheritance of personal possessions of the dead, and whether any of these objects had functioned affectively as mementoes, or as part of a family's material archive.

In both instances, whether it was a question of forensic identification, or keepsakes in the home, the theme of the possessions of the dead could elicit strongly animated responses, and more emphatically certain responses than other lines of questioning about the dead. Certain key items of clothing, jewelry and possessions of the dead would be invoked in detail but it rapidly became clear that these items could not be recovered from the grave. They were no longer on the bodies of the dead, nor in their family home, because the objects in question had been stolen at the time of the murders, and often ostentatiously displayed by the perpetrators of the killings or their associates.

I became interested in the clarity and precision with which these stolen objects were remembered in these communities, and in the enthusiasm with which they recounted the thefts. These episodes of theft and display were a safer topic of conversation that drew in visitors to the grave edge during the exhumations. Different visitors, even middle-aged individuals who had no firsthand memory of the deaths and otherwise professed their ignorance over what had happened, could chime in and confirm the theft of a specific object. This strongly suggested that the theft of objects had been a safer theme in the intergenerational transmission of memory in the decades preceding the mass grave investigations. Several speakers became highly indignant when recalling these thefts:

Another old man whom they killed some days after, this man had a corduroy suit, and they took it off him to put on another one, and another from my village had a new belt for his trousers, they took it off him, and there was one man from Fuentes who was using it until very recently. Look at the fainas [burdens] we go through. (Tina, Villavieja, Burgos Province)

I noted a discussion of a particular corduroy suit in which the participants agreed that it had been an expensive, fashionable, newly-purchased suit that was so distinctive that 
it was immediately recognizable when the killer returned wearing it. In the course of this discussion no direct memories were elicited of the life history of the original owner of the suit, despite the fact that the remains of his body were in close proximity. Knowledge of the perpetrator's identity was claimed by all those present, but his actual name was never used in the discussion, a form of self-censorship that I observed in almost every discussion on the past throughout my fieldwork, and that other investigators reported too. Perpetrators' names remained an absolute taboo, regardless of the speaker or the context. In small communities where perpetrators, victims and their descendants continue to live in close proximity, it would be considered inflammatory and destabilizing to directly name a perpetrator, although speakers sometimes indicated, in coded ways, that their names were known.

The narratives of theft strongly encoded claims about the motivations of the killers, the underlying causes of the violence, and the morality of the perpetrators. These claims can be seen in this account by an informant who lost a number of male relatives on her mother's side:

We were informed that they went to Burgos. We didn't know anything else, we found out later when we saw people wearing their clothes. The ones who took them away were wearing their clothes. It was some bosses from the village, but they ordered some people to kill them for a crust of bread, and one of my uncles wore a gold signet ring, very good, because he'd been in France, and they cut off his finger to remove it. All that, we know. (Ana, Villavieja, Burgos Province)

Evoking the stolen clothes, the crust of bread, and the gold ring, this narrative implies a certain economy of the objects that surround these deaths. The theft of clothes makes the killers into common criminals. The crust of bread that prompted the killings may refer to actual food, although the expression "un cacho de pan" was used figuratively in my field sites, for trifling amounts of money, or goods of little value. It is a useful metaphor in this case, as bread communicates real material need or hunger and thus partially absolves the killers, or at least diminishes their free will. Moral responsibility is located with the "bosses," and the guilt of the perpetrators is dispersed or diffused. The detail of a covetable gold ring and the violence of the severed finger convey a real sense of abjection. The depravity of the perpetrators, and the transgressive nature of 
these acts, can be conveyed without explicitly condemning them. Instead, the act is left to speak for itself. The element of shameless display (also invoked for a belt and a corduroy suit) is particularly chilling. The appropriation of these stolen clothes served to announce the deaths. The moment of dissonance, in recognizing familiar clothing on the body of another, followed by the vertiginous realization of what this signified, encapsulates much about the experience of defeat in these small communities.

The objects invoked here communicate an intimate connection with the dead. A suit of clothes takes on the form of its wearer, and the ring cannot be separated from its owner without dismembering his finger. Recalling the wholesale appropriation of homes and businesses in a town in Extremadura, after a number of the middle-class members of the town council were either killed or driven out, a local informant noted:

They didn't just take the wardrobe, but the clothes hanging in the wardrobe. Not just the dresser, but the plates in the dresser. (Eulalio, Extremadura)

To me, this eloquently conveyed the comprehensive nature of the theft, and asserted a moral judgement. The perpetrators were insatiable. They re-used intimate objects such as clothes, an unheimlich act which reanimates the dead. They grubbily adopted secondhand domestic goods that had been used by others, with none of the affective or familial connection that naturalizes the inheritance of such objects. They transgressed notions of privacy, and the sacrosanct nature of domestic spaces, that are so stronglyheld in rural Spain. More profoundly, this wholesale and immediate post-mortem appropriation meant that every corner of space vacated by the dead was immediately filled, leading to a full erasure, not only of the living person but of their absence too. This disturbed the deeply ingrained conceptions of the social space that should be left by a death, and gradually repaired by proper mourning. The theft also touched upon some of the categorical instability we feel around the impersonation of the dead, and a confusion of identity between living and dead. The sense of moral instability and ambivalent sentiments evoked by appropriated goods, especially those intimate domestic goods, that somehow retain the affective trace of their former owner, is insightfully explored by Navarro-Yashin (2009) in the context of the war in Cyprus. From this perspective, it is not surprising that these acts of appropriation leave a lasting psychic wound well beyond the injury of a material loss. 


\section{The Memory Politics of Theft and Envy}

The above discussion highlights the ways by which narratives of theft and envy can encode moral judgments on the perpetrators, but they also make claims about the 'innocence' of the victims within the logics of political violence that dominated during this period. Within the framework of Francoist rhetoric, which excoriated the dead as the Bolshevik hordes, or the "anti-Spain", a claim of exceptionality can be made for one's own particular relative. So, whilst some victims were necessarily killed for being "Reds", one's own relative was opportunistically killed for his suit, watch, or money. In the culture of reprisals and collective punishments that followed the war, this impulse can be readily understood. For relatives of the dead, to describe one's own particular bereavement as materially motivated was an act of self-preservation, in order to downplay the Republican identity of the victims. Whilst undoubtedly true, this is a simplistic and instrumentalist reading of these narratives that misses much of what they can tell us the experiences of loss and survival in these communities.

In conducting fieldwork, I was able to observe the Republican memory campaigners, local co-ordinators, and specialists working on the mass grave investigations, as they encountered examples of these narratives of material theft and envy. I was able to gauge their immediate responses, and also record their extended reflections upon the repression of memory. As a generalization, local co-ordinators and volunteers were steeped in the memory idiom of lost objects, finding the thefts a compelling and resonant part of the investigations, and broadly accepting the logics of material envy as a cause of violence. By contrast, those memory campaigners who were politicallyengaged or historically well-informed, repeatedly manifested frustration and impatience with narratives of theft or envy, sometimes rejecting them outright.

These campaigners are hugely knowledgeable and experienced in the investigation of Civil War violence. They comprehend the violence done to memory by decades of a repressive regime, and they work tirelessly to reverse the legacy of this repression. Yet, it is also possible to reframe narratives of theft and envy as politically expressive, rather than muted. Unpacking the resonance of these stories reveals more about the full spectrum of Francoist repression and the mechanisms by which they impacted on 
victims and survivors. They are highly revealing of the routes by which memory, affective entanglements with the dead, and a legacy of pain and loss, have been transmitted. The act of reframing these narratives exposes gaps in the investigative paradigm of mass grave investigation, which cannot adequately capture the full range of traumatic experiences, namely the residual pain of 'slow' or structural violence.

Confronted with death and physical injury on the scale of the Spanish Civil War, it is understandable that material losses may appear a marginal concern. But this ignores the potentially devastating impact of systematic dispossession, and its complex links to physical suffering and death. There is a growing recognition of the significance of material loss in the field of Holocaust studies. Whilst there are extensive debates on how Holocaust scholarship should inform current historiography of the Spanish Civil War (see Marco, 2017; Preston 2012; Baer \& Sznaider, 2015), recent work on theft in the Holocaust provides a number of important insights. In Robbing the Jews Dean (2008) notes the lack of scholarly attention hitherto given to all the different strategies of theft and appropriation that accompanied the progressively worsening persecution of Europe's Jews. He observes that given the wholesale destruction of people, these material concerns appeared secondary. On first sight it might appear morally distasteful or unsettling to attend to material possessions in the face of mass killings. However, more recent scholarship reveals the extent to which material exploitation occurred at every juncture of the Holocaust, it was not merely adventitious or incidental (Dean, 2008). The appropriation of Jewish goods extended to the most abject acts, such as the systematic postmortem processing of the dead in death camps, and digging over decomposing bodies, graves and ash for any final remnants of value, missed in these preceding stages (Dziuban, 2016; 2015).

This reflects an increasing awareness that the fate of people, and the fate of their possessions, are inextricably linked during war and political violence. On the most pragmatic level, the loss of material things at a time of war dramatically reduces the chance of survival. These resources could potentially be exchanged for food or shelter, or used to secure safe passage away from danger. Stripping a person of all assets, at the moment when their social or legal status is at its most precarious, can be an act of fatal violence (Dean, 2008; Gerlach, 2017). 
An elderly informant in a rural community in Burgos, spoke repeatedly about the malign force of envy, and of the theft of particularly covetable or desirable objects, but also spoke explicitly about the politics of systematically enforced material deprivation. The two explanatory frameworks were not mutually exclusive in his understanding of the past. The particular episodes of theft were his entry point to recalling dispossession, and its devastating effects. He linked poverty to the high levels of infant mortality amongst the surviving Republican families, including children who were his peers, underscoring the fact that the systematic dispossession of Republican families had life or death consequences. His own memories of daily poverty were still painful for him, and I sensed a struggle between his strong sense of personal dignity, and his desire to convey the realities of that period:

We ate bread and onions, and not so much of that either! When disease comes, you just know which children will be carried off. Round here, they refused to vaccinate the children of Reds. Imagine such hatred, to refuse a vaccine to a child. (Alfonso, Burgos Province)

It is revealing here that a memory of material poverty segues immediately into a recollection of the othering of Republicans as 'Reds', and their postwar experience of prejudice and persecution. One of the most important insights furnished by the study of the mass appropriation of property in the Holocaust is the extent to which it is not simply an economically motivated crime, but a concerted strategy of dehumanization and othering. Forms of violence against property, including theft, can be understood in the wider context of acts of violence and debasement of the victims' bodies, both living and dead (Dziuban, 2015). The dehumanization of the targeted group is a precursor to the breakdown of social and legal norms surrounding their property, but acts of dispossession also further enact and compound this otherness, in an iterative process. The impulse to enact exclusion and destruction may well be intertwined with economic motives or 'rational' self-interest. However, in post-hoc explanations it may be more palatable to foreground the economic motives of greed or scarcity, rather than acknowledge the full violence of these acts.

\section{Material Truths and Structural Violence}


Following the Civil War, Spain experienced extreme economic hardship, which fell disproportionately on the losing side. Hernandez Burgos (2016) notes the degree to which widespread hunger and deprivation shaped post-war Spanish society, and served to consolidate Francoism. Vázquez Montalban (2003) described this post-war period as 'the reign of material truths', after the clash of ideologies and wider culture wars that dominated the 1930s. Graham (1995) has identified a corresponding 'reign of material myths', in which remembered and yearned for objects, emblematic of the time before war and austerity are invoked in popular culture, songs, and images in postwar Spain. The fetishizing of unattainable goods offered a kind of coded resistance and outlet for loss, in a time of heavy state censorship. This focus on seemingly mundane objects as indices for yearning, nostalgia, and grief has strong parallels with the psychic weight accorded to stolen objects in my field sites, even the most mundane and basic items. Very elderly informants could describe, with great clarity, the theft of consumable goods such as olive oil, lentils, fruit and flour. Similarly, in a moving account of how the memories of Holocaust survivors are transmitted within their families, Kidron (2012) describes how a plain, worn out, metal spoon attains talismanic status in one family home. It was an essential tool, symbolizing physical survival in the camps. Despite its provenance from such as horrible place, the spoon is in the cutlery draw and in daily use, underscoring its material insistence on the continuation of life.

The narratives of theft and dispossession, and the associated experience of poverty in postwar Spain, powerfully illustrate the impact of 'slow' or structural violence on a community, over multiple generations. Different forms of violence, such as structural, symbolic, or 'everyday', defined in part by their source, and in part by their mechanisms of action, have been theorized extensively by Scheper-Hughes (1992; 1996; 1997), Bourgois, Farmer (2004), and, more recently Nixon (2013). Slow violence is 'violence that occurs gradually and out of sight; a delayed destruction often dispersed across time and space' (Nixon, 2013). This accords with informant accounts of the experience of Republican families, with multiple episodes of theft, exploitation and harassment, recurring in the 1940s and even 1950s. These injustices were incremental, cumulative, and grinding. Scheper-Hughes and Bourgois (2004), in particular, map the intersection between different registers of violence, often mutually constitutive, and stress the ethical imperative to note violence that may be masked by more conventional manifestations of aggression, such as warfare. 
It is important to be attentive to the kind of discussions of theft that occurred at the graveside during the exhumations, as detailed at the beginning of this article, precisely because they reflect a collective and spontaneous impulse to presence 'slow' violence, just at the moment when episodes of 'fast' or cataclysmic violence are being exposed. After years of repression and silence, the exhumations create a radical rupture, and a space to investigate and represent the Republican experience. But the forensic and archaeological paradigm employed in these investigations, and the primary focus on the bodies and graves as the corpus delicti, or substance of the crime, impose a narrow definition of Republican suffering and loss.

\section{Gender, Family Memory and Stolen Objects}

The daily struggle for survival, characterized as the reign of material truths, crowded out political opposition and made the entire population more compliant. However, there is an important gendered element to this particular manifestation of slow violence. The mass-killing of Republican men left behind thousands of female-led households, where newly-bereaved women were responsible for the survival of their children and dependents. Ryan (2009) and Amir (2019) document the targeted destruction of Republican family units, and the mass conscription of surviving Republican women, and their children, into a gamut of corrective state institutions such as prisons, schools and orphanages. Attacking the economic self-sufficiency of these households, through repeated episodes of theft and exploitation, hastened this process of enforced dependency. A single family could be subjected to the robbing of the dead, the looting of their possessions, and then imposition of retroactive 'fines' for their political allegiances (Del Arco Blanco \& Anderson, 2017; Renshaw, 2011). The struggles that occurred in these female-led households in the wake of the mass killing of male Republicans is vital to appreciating the enduring psychic hold of these stolen objects. The capacity of these lost objects to function as indices of female experience, and the female relatives in Republican households, is central to understanding why these narratives of theft surface strongly at the moment of exhumation, and why these lost objects are apparently recalled with such clarity and focus. 
My strong impression of the way stolen objects, and episodes of theft, were described by informants, was of reported speech, transmitted directly from their own mothers and female relatives. A similar impression of reported speech, direct from the mother, is noted movingly in the ethnographies concerning this period (Fernandez de Mata, 2010; Ryan, 2014; Schmoll, 2014). I sensed that my elderly informants could visualize the lost objects distinctly, despite the fact that they had never seen them. This was in stark contrast to the hazy and faltering memory that surrounded either the murdered individuals, or the political circumstances of the killings. These narratives are indicative of the kinds of muted and anguished communication that went on within Republican homes. During a period when there were such strong taboos around speaking of the dead, and an absolute impossibility of speaking about the sexual violence experienced by many Republican women, material loss could be spoken about more safely. In this postmemorial context, dominated by silences and unanswered questions, narratives of stolen objects filled a vacuum for children in Republican homes. The daily negotiation of poverty and survival would bring the loss of particular objects to the fore again and again. Years of material deprivation meant the injustice of these losses would be felt afresh and lamented bitterly in front of children growing up in these homes.

The mass grave is a snapshot of a brief, intense moment of violence. It cannot act as an index of these other forms of slow, diffuse, or structural violence. Even whilst ostensibly broadening the scope of war memory, by investigating the killings of civilians, rather than combatants, mass grave investigations also reproduce certain narrow understandings of warfare. The focus on dead bodies in the grave reproduces our understanding of killing as the primary or defining act of war. It is difficult for a mass grave investigation to give representational space, or symbolic weight, to a parallel war narrative, which is the drawn-out endeavour of survival. The preponderance of male victims in the graves risks masking the breadth of experiences that constituted the Civil War, particularly the female civilian experience. The attention commanded by mass grave investigations is vitally important yet risks neglecting the central place of women in post-war survival, and the affective imprint these women have left on surviving generations.

The memory of slow violence, and the memory of those Republican women who endured it, may be as emotionally resonant for the descendants of the dead as the bodies 
of the murdered men, many of whom they never know firsthand. Multiple investigators and oral historians in Spain have noted the profound and almost unutterable forms of grief, guilt and anger that are uncovered amongst the children of Republican families, when the focus of testimony moves onto the mothers and grandmothers who raised them (Fernández de Mata, 2010; 2004; Ferrándiz, 2010). A central regret, expressed by many relatives of the dead, is that the great majority of those women did not live to see the contemporary mass grave exhumations or the current resurgence in Republican memory, so in an important sense, these exhumations have come too late.

\section{Survivance, Postmemory and the Materiality of Lost Objects}

In thinking through the persistent imaginative hold of the stolen objects, many of which were never witnessed firsthand by any of the narrators of these thefts, and the shadow presence of the Republicans who survived war and endured dictatorship, the notion of survivance is a useful conceptual tool. It offers a way of exploring the affective power of lingering traces, or a middle category between presence and absence, and of ways of recognizing the strength of survival without framing this survival in a redemptive narrative. Dziuban (2017) has highlighted the potential of this multivalent term to express the complex qualities of both the material traces of destruction, and the experiences of those people and cultures who have passed through destruction. Originated by Derrida to capture the stubbornness of ashes, as residual traces that persist after a seemingly total act of destruction, Dziuban also notes the other incarnation of the term as developed by Vizenor (2008) to theorize the cultural condition, and possible forms of expression, in the wake of the extreme violence of colonization.

The word reflects a merging of survival with revenance, but also alludes to persistence, and perhaps, to adapt it to the Spanish case, endurance. It is not simplistically redemptive or celebratory in that it identifies a form of survival 'that does not revoke eradication', and thus rejects destruction and survival as a binary opposition. The description of survivance employed by Vizenor 'bearing traces of and calling forth the shadows of reality eradicated through violent processes' (Dziuban, 2018, 286; Vizenor, 2008,17 ), is strongly evocative to me to the way informants in these communities spoke 
about both the theft of their material possessions, and the lives of the women who raised them. The speakers are indelibly marked by these memories and actively seeking to presence them during the mass grave investigations. They express the twin impulses to attest to the suffering that they lived through, but also attest that they did indeed live through. The dual threads of suffering and survival, holding the two in tension, and giving both their due weight, is arguably characteristic of the timescales involved in the Spanish exhumations, and the fact that so much of the testimony is necessarily located in memories of childhood. Ribeiro de Menezes (2014) notes this dual quality in both oral history and cultural expressions that draw on post-war childhood in Spain. She describes these childhoods as 'haunted by fear, repression and loss', and yet 'childhood suffering is accompanied by a forward looking emphasis on resistance and resilience' (ibid. 2014, 88).

The way in which stolen and irretrievably lost objects perform a memorial function in these narratives reverses or disrupts many of the ways in which objects are conventionally understood to stand in for the missing and the dead, and how real, tangible objects may elicit testimony, and structure the process of mourning. To a degree, these stolen objects elude much of material culture theory. However, Clark (2013) convincingly argues for a greater range of 'mnemonic objects' in the aftermath of war and genocide, and an attentiveness to how specific histories shape the memorial forms that emerge. Writing on the Holocaust, Gerlach (2017) acknowledges that a material culture analysis of lost objects 'might seem quixotic' but notes that for the dispossessed, objects continue to exist as absences (ibid. 17). Bille et al. (2010) assert that the material culture of missing things is fruitful and necessary because 'the absent elements are sensuously, emotionally and ideationally present to people' (ibid, 3). The mnemonic power of absence, and the conceptual and aesthetic paradoxes it raises, are interrogated brilliantly in Sturken's (2004) analysis of the struggle to commemorate the destruction of the World Trade Centre in New York, and the emergence of the 'void' as the most fitting memorial form for this site.

In the Spanish context, these objects are imaginary but powerfully real and their physical characteristics can be described by individuals who never saw them firsthand, (and even by the children of those who never saw them firsthand). For the particular 
category of stolen objects, part of this almost tangible presence resides in their power as agentive objects. The culturally-specific understandings of material envy, its causes and mechanisms, place the envied object as a central actor in the narrative. Envy operates in a triangle between the perpetrator who feels envy, the coveted object that draws their eye, and the unfortunate owner of that object who falls victim to envy (Gilmore, 1987; Pina-Cabral, 1986; Renshaw, 2011).

When the coveted objects are invoked as a primary motive for the killings, thefts and dispossession that occurred in these communities, they are ascribed agency in these acts, and the envied object becomes pivotal in the biographies of the murdered men. By eliciting murderous envy in the perpetrator, a coveted object seals the fate of those who died. Several of the descriptions of stolen objects that appear to recall details of the object, are primarily emphasizing the desirability or rarity of the object, thus emphasizing its agentive power to draw the envious gaze. Following the logics of envy, the objects in these narratives possess the fatal flaw of being too desirable, to the wrong person, at the wrong moment. Certain objects, such as the gold ring cut from the finger of its dead owner, are charged with a violent energy, because of the malign acts they inspire. It is unsurprising that the visual, material and sensory qualities of coveted objects somehow burn brighter than other material things, and command a strong psychic hold.

The theory of postmemory as proposed by Hirsch (1996; 1997), would suggest that precisely by being absent, the compelling properties of these stolen objects are sustained over time: 'Postmemory is a powerful and very particular form of memory precisely because its connection to its object or source is mediated not through recollection but through an imaginative investment and creation' (Hirsch, 1996; and see Hirsch, 2008). However, this postmemorial characteristic of the stolen objects, that they are essentially imagined, or irretrievably lost, creates a tension with the project to 'recover' Republican memory. The paradigm of recovery, especially as aligned with, and structured by, archaeological and forensic investigations, inherently privileges the real and the tangible. The opening up of mass graves results in the sudden and dramatic proliferation of material traces of the past. The past is intensively materialized across a range registers including human remains, the clothes and possessions of the dead, bullets and casings, and the associated photos, letters, military orders, warrants and 
archival records assembled by the investigative teams. The intense materiality of the grave has a saturating effect. The profusion of new evidence from the graves risks displacing the ephemeral and imaginary memory objects that have endured in these communities, meaning their associated narratives are also overlooked.

\section{Conclusion}

Given the secrecy and denial that has surrounded the mass graves in so many communities, and the history of social erasure and exclusion that was inflicted on the defeated Republicans, the materiality of those bodies and objects recovered from the graves is powerfully effective in bringing the dead back into the public realm. They are incontrovertible evidence that these deaths occurred. The bodies and objects in the graves are disturbing, moving, evocative and compelling. As the mortal remains of the dead, they enable acts of mourning and affective engagement that were hitherto impossible. However, it is important to remember that the dead are not reappearing in a vacuum. The newly-emerging bodies and objects in the grave have to be brought into an assemblage, and affectively reconciled with, the existing suite of memorial objects, even if these are only imagined. The memorial forms that pre-date the mass grave exhumations, particularly narratives of theft and envy, may be muted or conditioned by the dictatorship, but they are also expressive of profound experiences of dispossession and the struggle to survive. The physical traces of these experiences will not be recovered from the graves.

The lost and stolen objects evoked in these narratives are the material indices of other forms of suffering, and other victims of the war. The ways in which these stories emerge during the mass grave investigations, and the reasons why theft and envy are invoked at this juncture are complex. The emergence of these stories are revealing of the interweaving between memory, repression, fear and survivance in the Spanish context. Just as the stolen objects are dispersed, and cannot be recovered from the grave, the bodies and biographies of the women who survived the war, and endured the dictatorship, will not be recovered from these mass graves. They died decades later and are buried elsewhere. The ghostly objects invoke the women who are missing from the mass grave paradigm and briefly make these women present at the graveside. Their stories are threaded together and run as a kind of parallel narrative, or shadow narrative, 
alongside the more predominant representation of violence afforded by the mass graves. By invoking stories of survivance during a mass grave investigation, the narrators complicate any simple reading of exhumation as a redemptive act.

When narrowly applied, the mass grave paradigm artificially limits the material traces, victims, and time-frames encompassed in the scope of war memory. The mutuallyengaged and generative relationship between mass grave excavations, and new cultural responses to the past, has been particularly powerful in Spain (Ferrán, 2013; Baer \& Ferrándiz, 2008; Ferrándiz, 2016). However, the narratives of lost objects discussed here have wider implications, both in and beyond Spain, in the development of those practices at the intersection between post-conflict investigation and post-conflict commemoration. The category of lost objects is inseparable from war. For the objects considered here, it is precisely their material absence that confers a powerful form of survivance. A clear implication is the necessity for archaeology, particularly forensic archaeology, so grounded in the empirical and tangible, to broaden its conceptual understanding of materiality, of what constitutes a burial assemblage, and what constitutes the material record. In work as vital and sensitive as this, archaeology needs to deploy new creative and reflective practices to attend to the affective and imaginative traces of the past. This means bringing the physical bodies and objects recovered from the graves into a broader conception of assemblage, situating them in their memorial context of lost, remembered, and imagined objects.

There is already a phenomenal (and growing) body of work on women and the Spanish Civil War (including Box 2017b; Graham 1995a; Hermann 2003; Ryan 2009; Sole 2017). Whilst this scholarship is highly attentive to gender, features of the mass grave paradigm still resist this turn. It is necessary to think critically about the framing of the past created by an open grave, and not permit that frame to become an exclusionary boundary determining whose experiences are investigated, recorded and commemorated. Many war victims (frequently female war victims) are missing from the grave itself and so may end up missing from the exhumation process. When searching inside a grave, it is imperative to also look for traces of those who figuratively stand at the grave's edge. For each of the dead, there were also terrorized, bereaved, and materially dispossessed individuals, who survived. One practical way to broaden the frame is to bring the concepts of slow or structural violence more fully into post- 
war investigation and commemoration. Documenting the cataclysmic events of a massacre or a clandestine burial is vital work, but the full interpretation of a mass grave requires a longer narrative, situating the event in a wider arc of slow violence. Importantly, this entails looking back in time, to include the structural inequalities and othering that are so often precursors to a mass grave, as well as documenting the complex aftermath of violent episodes, the forms of repression that may persist for years afterward, and the experiences of those who survived.

\section{References}

Aguilar P (2002) Memory and Amnesia: The Role of the Spanish Civil War in the Transition to Democracy. New York: Berghahn Books.

Amir, R (2019) Twentieth Century Forcible Child Transfers: Probing the Limits of the Genocide Convention. New York: Lexington Books.

Baer, A. \& Sznaider, N. (2015) Ghosts of the Holocaust in Franco's mass graves: Cosmopolitan memories and the politics of "never again" Memory Studies, Vol. 8(3) $328-344$.

Baer. A. \& Ferrándiz, F. (2008) "Digital Memory: The Visual Recording of Mass Grave Exhumations in Contemporary Spain.” Forum: Qualitative Social Research 9(3) Article 35.

Bevernage B and Colaert L (2014) History from the grave? Politics of time in Spanish mass grave exhumations. Memory Studies 7(4): 440-456.

Bille M., Hastrup F and Sorensen T (eds) (2008) An Anthropology of Absence: Materializations of Transcendence and Loss New York: Palgrave. 
Box, Z (2017a) The "corporealization" of the Nation: Notions of the Unclean and Viscosity in the Nationalist Discourse of Spanish Fascism Journal of Spanish Cultural Studies 18(1) 1-19.

Box, Z (2017b) The Simple Geometry of Linearism: Metaphors of the Nation in the Radical Falangist Discourseof the Immediate Postwar Period in Spain Journal of Historical Sociology 30(2) 143-163.

Casanova J and Cenarro A (2014) Pagar las culpas. La represion politica en Aragon (1936-1945). Barcelona: Critica.

Clark LB (2013) Mnemonic Objects: Forensic and Rhetorical Practices in Memorial Culture. M. Silberman and F. Vatan (eds) Memory and Post-War Memorials: Confronting the Violence of the Past. New York: Palgrave pp.155-173.

Dean M(2008) Robbing the Jews: The Confiscation of Jewish Property in the Holocaust, 1933-1945 New York: Cambridge University Press, with the United States Holocaust Memorial Museum.

Del Arco Blanco MA and Anderson P (2017) Property, the forging of Francoism and collective memory in International Journal of Iberian Studies 30(2): 73-92.

Dziuban, Z. (2016) The Things that Affectively Live On: The Afterlives of Objects Stolen from Mass Graves in S:I.M.O.N, Shoah: Intervention, Methods, Documentation $2016(2): 25-36$

Dziuban Z (2015) The Politics of Human Remains at the 'Peripheries of the Holocaust' in Dapim: Studies on the Holocaust 29 (3): 154-172.

Dziuban Z (2017) Between Subjectification and Objectification: Theorising Ashes. Dziuban Z (ed) Mapping the Forensic Turn. Vienna: New Academic Press pp.261-290.

Etxeberria F (2016) Listado de exhumaciones llevadas a cabo en España desde el año 2000. http://www.politicasdelamemoria.org/wp- 
content/uploads/2015/09/Exhumaciones-desde-el-a\%C3\%B1o-2000-CSIC.pdf Accessed 30 Jan 2018

Farmer P (2004) An Anthropology of Structural Violence. Current Anthropology 45 (3): 305-325.

Fernández de Mata F (2010) The Rupture of the World and the Conflicts of Memory. In: Jerez-Farrán C, Amago S (eds) Uneathing Franco's Legacy: Mass Graves and the Recovery of Historical Memory in Spain. Notre Dame: University of Notre Dame Press, 279-303.

Ferrán O (2013) “Grievability and the Politics of Visibility: The Photography of Francesc Torres and the Mass Graves of the Spanish Civil War." Memory and Postwar Memorials: Confronting the Violence of the Past. Ed. Marc Silberman and Florence Vatan. New York: Palgrave Macmillan, 117-36.

Fernández de Mata I (2004) The "logics” of violence and Franco's mass graves: An ethnohistorical approach. International Journal of the Humanities 2(3): 2527-2535.

Ferrándiz F (2006) The Return of Civil War Ghosts: The Ethnography of Exhumations in Contemporary Spain. Anthropology Today 22(3): 7-12.

Ferrándiz F (2010) The Intimacy of Defeat: Exhumations in Contemporary Spain. In: Jerez-Farrán C, Amago S (eds) Uneathing Franco's Legacy: Mass Graves and the Recovery of Historical Memory in Spain. University of Notre Dame Press, Notre Dame, pp. 304-325.

Ferrándiz F (2016) "From tear to pixel: political correctness and digital emotions in the exhumation of civil war mass graves in Spain today" in LE Delgado, P. Fernandez, and J. Labanyi. (eds) Engaging the Emotions in Spanish Culture and History, Nashville, Tennessee: Vanderbilt University Press, 242-61.

Fidalgo, P (1939) A Young Mother in Franco's Prisons. London: United Editorial. 
Gerlach D (2017) Toward a Material Culture of Jewish Loss in Jewish Culture and History 18(1): 17-33.

Gilmore D (1987) Aggression and Community: Paradoxes of Andalusian Culture. New Haven: Yale University Press

González-Ruibal A (2007) Making Things Public: Archaeologies of the Spanish Civil War. Public Archaeology 6(4): 203-226.

Graham H (2004) The Spanish Civil War, 1936-2003: The Return of Republican Memory. Science and Society 68(3): 313-328.

Graham, H (1995a) Gender and the State: Women in the 1940s. In H Graham and J Labanyi (eds) Spanish Cultural Studies: An Introduction. Oxford: Oxford University Press.

Graham, H. (1995b) Popular Culture in the "Years of Hunger." In H Graham and J Labanyi (eds) Spanish Cultural Studies: An Introduction. Oxford: Oxford University Press.

Hernández Burgos C (2016) The Triumph of 'Normality', Social Attitudes, Popular Opinion and the Construction of the Franco Regime in Post-War Rural Spain (19361952) European History Quarterly Vol. 46(2) 291-310.

Herrmann G (2003) Voices of the vanquished: Leftist women and the Spanish Civil War in Journal of Spanish Cultural Studies 4(1): 11-29.

Hirsch M (1996) Past Lives: Postmemories in Exile. Poetics Today 17: 659-686.

Hirsch M (1997) Family Frames: Photography, Narrative and Postmemory. Cambridge: Cambridge University Press.

Hirsch M (2008) The Generation of Postmemory. Poetics Today 29(1): 103-128. 
Kidron C (2012) Breaching the wall of traumatic silence: Holocaust survivor and descendant person-object relations and the material transmission of the genocidal past. Journal of Material Culture 17(1): 3-21.

Lines L (2009) Female Combatants in the Spanish Civil War: Milicianas on the Front Lines and in the Rearguard. Journal of International Women's Studies 10(4): 168-187.

Maestre, A. (2019) Franquismo S.A. Madrid: Ediciones Akal.

Marco, J (2019) 'Rethinking the Postwar Period in Spain: Violence and Irregular Civil War, 1939-52', Journal of Contemporary History 1-22.

Marco, J. (2017) Francoist Crimes: Denial and Invisibility, 1936-2016 Journal of Contemporary History Vol. 52(1) 157-163.

McDowell S (2008) Commemorating dead 'men': gendering the past and present in post-conflict Northern Ireland. Gender, Place and Culture 15(4): 335-354.

Moon C (2013) Interpreters of the Dead: Forensic Knowledge, Human Remains and the Politics of the Past. Social and Legal Studies 22(2): 149-169.

Moon C (2014) Human rights, human remains: forensic humanitarianism and the human rights of the dead. International Journal of Social Sciences 65(215-216): 49-63.

Navarro-Yashin Y (2009) Affective Spaces, Melancholic Objects: Ruination and the Production of Anthropological Knowledge Journal of the Royal Anthropological Institute Vol.15 1-18.

Nixon R (2013) Slow Violence and the Environmentalism of the Poor Cambridge, MA: Harvard University Press.

Osborne R (2011) Good girls versus bad girls in early Francoist prisons: Sexuality as a great divide. Sexualities 14(5): 509-525 
Pina-Cabral J (1986) Sons of Adam, Daughters of Eve: The Peasant World View of the Alto Minho. Oxford: Oxford University Press.

Preston P (2012) The Spanish Holocaust: Inquisition and Extermination in TwentiethCentury Spain. London: Harper Press.

Reading A (2002) The Social Inheritance of the Holocaust: Gender, Culture and Memory. New York: Palgrave.

Renshaw L (2011) Exhuming Loss: Memory, Materiality and Mass Graves of the Spanish Civil War. Walnut Creek: Left Coast Press.

Ribeiro de Menezes A (2014) Embodying Memory in Contemporary Spain. New York: Palgrave.

Richards M (1998) A Time of Silence: Civil War and the Culture of Repression in Franco's Spain: 1936-1945. Cambridge: Cambridge University Press.

Richards M (2001) Morality and Biology in the Spanish Civil War: Psychiatrists, Revolution and Women Prisoners in Málaga. Contemporary European History 10(3) $395-421$

Richmond K (2014) Women and Spanish Fascism: The Women's Section of the Falange 1934-59 London: Routledge/Canada Blanch Studies on Contemporary Spain.

Ríos L and Etxeberria F (2016) The Spanish Civil War Forensic Labyrinth. In: Ferrán $\mathrm{O}$ and Hilbink L (eds) Legacies of Violence in Contemporary Spain: Exhuming the Past, Understanding the Present. New York: Routledge, pp.44-68

Ríos L, García-Rubio A, Martínez B et al (2014) Patterns of perimortem trauma in skeletons recovered from mass graves from the Spanish Civil War (1936-1939). In: Knüsel C, Smith MJ (eds) The Routledge Handbook of the Bioarchaeology of Human Conflict. Routledge, London, p 621-640 
Rodrigo J (2008) Hasta la Raiz. Violencia durante la Guerra Civil y la Dictadura Franquista. Alianza, Madrid

Rosenblatt A (2015) Digging for the Disappeared: Forensic Science after Atrocity. Stanford University Press, Stanford

Ryan L (2009) The sins of the father: The destruction of the Republican family in Franco's Spain. Journal of Family History 14: 245-252

Ryan, L. (2014) Social Trauma and Motherhood in Postwar Spain in D. Cooper \& C. Phelan (eds) Motherhood and War. New York: Palgrave MacMillan

Sánchez Soler M (2003) Los Franco S.A.: Ascension y Caido de la Familia del Ultimo Dictator de Occidente Madrid: Oberon

Scheper-Hughes N and Bourgois, P (2004) Introduction: Making Sense of Violence in Scheper-Hughes, N and Bourgois, P (eds) Violence in War and Peace: An Anthology New York: Wiley pp.1-31

Scheper-Hughes N and Sargent C (eds) (1999) Small Wars: The Cultural Politics of Childhood. Berkeley: University of California Press.

Scheper-Hughes N (1992) Death without Weeping: The Violence of Everyday Life in Brazil. Berkeley: University of California Press.

Scheper-Hughes N (1996) Small Wars and Invisible Genocides. Social Science and Medicine 43(5): 889-900.

Scheper-Hughes N (1997) Peace-Time Crimes. Social Identities 3(3) 471-497.

Schmoll, B (2014) Solidarity and Silence: Motherhood in the Spanish Civil War. Journal of Spanish Cultural Studies 15(4): 475-489

Silva E (2000) Mi abuelo también fue un desaparecido. La Crónica de León, 8 October 
Silva E and Macías S (2003) Las Fosas de Franco: Los Republicanos que el Dictador Déjo en las Cunetas. Madrid: Temas de Hoy

Sole Q (2017) Executed Women, Assassinated Women: Gender Repression in the Spanish Civil War and the Violence of the Rebels in Ferrán O \& Hilbink L (eds) Legacies of Violence in Contemporary Spain: Exhuming the Past, Understanding the Present. New York: Routledge, pp.69-92

Steele C (2008) Archaeology and the Forensic Investigation of Recent Mass Graves: Ethical Issues for a New Practice of Archaeology. Archaeologies 4(3): 414-428.

Sturken, M (2004) The Aesthetics of Absence: Rebuilding Ground Zero. American Ethnologist 31(3): 311-325.

Tremlett G (2006) Ghosts of Spain: Travels through a Country's Hidden Past. Faber and Faber, London

Vázquez Montalbán, M (2003) Cronica sentimental de España. Barcelona: Debolsillo.

Viñas A (2015) La Otra Cara del Caudillo Barcelona: Crítica

Vinyes R (2002) Irredentas: Las presas politicas y sus hijos en las carceles de Franco. Madrid: Temas de Hoy.

Vizenor G (ed) (2008) Survivance: Narratives of Native Presence. London: University of Nebraska Press. 